\title{
Method of Buildings Structural Vulnerability and Geometry Form Designs Evaluation Towards Earthquakes with The SVA- Architectural Design
}

\author{
Livian Teddy $^{1 *}$, Gagoek Hardiman ${ }^{2}$, N. Nuroji ${ }^{3}$, Sri Tudjono ${ }^{3}$ \\ ${ }^{1}$ Architecture Departement of Sriwijaya University, Palembang, Indonesia \\ ${ }^{2}$ Department of Architecture, Universitas Diponegoro, Semarang, Indonesia \\ ${ }^{3}$ Department of Civil Engineering, Universitas Diponegoro, Semarang, Indonesia
}

*Corresponding e-mail: livianteddy@gmail.com

Article info:

Received: 17-04-2020, Revised: 25-04-2020, Accepted: 26-04-2020

\begin{abstract}
In the process of architectural design, there is no special method employed by architects to evaluate buildings' structural vulnerability and building geometry form designs towards earthquakes. Therefore, the alternative is adapting the existing method called SVA-Retrofit. JBDPA and Matsutaro Seki developed this method, and then the author adapted this method now called SVA Architectural Design. In the process of adaptation, deep literature review was conducted in order to acquire the adaptation results of the SVA-Architectural Design. The SVA analysis was then compared with the pushover analysis, and the results of SVA were actually accurate enough to predict the building vulnerability toward earthquakes. These results can furthermore be an early prediction of structural vulnerability toward earthquakes that eventually leads to finding solutions for building designs or conducting detailed analysis done by structure experts.
\end{abstract}

Keywords: Earthquake, Structural vulnerability and forms, SVA Architectural Design

\section{Introduction}

The earthquakeis the biggest challengefor physical development at earthquake-prone areas especially in the ones located in developing countries. These countries, having big population, are still conducting massive physical development in order to proper their people. According to the UNDP report (Pelling et al., 2004), the developing countries such as Indonesia, Philippine, India, Turkey, Afghanistan, and others suffered heaviest casualties inflicted by earthquakes from 1980 to 2000 . Most of victims experienced building collapse because of this disaster. The collapse not only occurred at the 'non-engineered' buildings but also occurred atthe 'engineered' buildings(Boen, 2006, 2007a, 2007b; Pawirodikromo, 2007; Ismail, Hakam and Fauzan, 2011). The 'engineered' buildings should have better resilience against earthquakes than the 'non-engineered' ones because the planning process of these 'engineered' buildings had already involved structure experts and architects(Çögürcü, 2015). Why does this problem happen? Internationally there is still a debate whether the matter of earthquake-resistant buildings is in the architects' domain or in the structure experts' domain (Wangsadinata, 2009). Actually, to create an earthquake-building needs good collaboration between architects and structure experts.

Architects, at least, have the knowledge and comprehension about basic seismic engineering, and structure experts, on the other hand, must comprehend functional needs and architectural aesthetics (Arnold, 1996). Having elementary knowledge and comprehension of seismic engineering, architects can identify and evaluate the vulnerability of building design towards earthquakes (Slak and Kilar, 2012). However, scientists have not developed the methods or the procedures of buildings vulnerability toward searthquakes especially for architects. The recently developed methods or procedures are too technical 
and difficult to be understood by architects (Özmen and Ünay, 2007). Therefore, it needs methods or procedures of structural vulnerability and building geometry form evaluations for building design processes.

The alternative is to adapt the method of building vulnerability evaluation towards earthquakes that has already existed called SVA (Simplified Vulnerability Analysis). The SVA is an evaluation method of the existing building's vulnerability towards earthquakes based on architectural and structural drawings. The Japan Building Disaster Prevention Association (JBDPA) (Okada et al., 2005) and Matsutaro Seki (Seki, 2015) intensively developed the SVA procedures of structural vulnerability and building geometry form evaluations towards earthquakes for retrofit purposes.Therefore, applying this method to evaluate buildings' vulnerability towards earthquakes in a developing country for design purposes needs modification. The SVA - Architectural Design proposed by the authors are limited to the structure of moment resisting frame, the structure of either one way or two way slab, the materials of reinforced concrete, and the multistory buildings having low rise to middle rise.

\section{Methods}

This research was a literature study divided into three parts. Basically the SVA from JBDPA and Seki considers that the condition is safe if the seismic index of structure $\geq$ the seismic demand index of structure. Based on the aforementioned fact, the exploration of this literature study consisted of three parts. The first part was the adaptation of the seismic index of structure, the second part was the adaptation of the seismic demand index of structure, and the third part was the comparison of the seismic index of structure and the seismic demand index of structure.

\section{Adaptation Process}

\subsection{The Adaptation of The Seismic Index of Structure $\left(I_{s}\right)$}

Generally the seismic index of structure was adopted from the procedures recommended by Matsutaro Seki (Seki, 2015) while some parameters in the index that are not in the procedures were adopted from JBDPA [12].

For a new building, the time index due to building's age depreciation and experiences in suffering earthquakes is assumed not influenced (the value $=1$ ), and the most influencing factors for a new building are the index of the basic seismic index of structure $\left(E_{0}\right)$ and the irregularity index $\left(\mathrm{S}_{\mathrm{D}}\right)$.

Therefore, the formula of the building's the seismic index of structure $\left(I_{S}\right)$ is:

$$
I_{S}=E_{0} \cdot S_{D}
$$

Where, $\mathrm{E}_{0}=$ the basic seismic structure index

$\mathrm{S}_{\mathrm{D}}=$ the irregularity index

\subsubsection{The Basic Seismic Index of Structure of Moment Resisting Frame Structure (Eo)}

There are some considerations in adapting the basic seismic index of structure namely: 
The lateral force resisting system is at least influenced by the redundancy, the dimension of columns, the stiffness of columns, strong column/weak beam, and structure ductility (Purwono, 2007).

Based on the previous fact, the JBDPA and Seki's comparison of the shear columns force and the floors'cumulative weight is adapted to be the width comparison between the columns and the floors $\left(\mathrm{I}_{\mathrm{AC}}\right)$ influenced by: the redundancy spelled out as the structure vibration period $\left(I_{T}\right)$, the column's stiffness spelled out as the ratio of column's height to column's width $\left(I_{C}\right)$, strong column/weak beam spelled as out the comparison of the number of columns fulfilling strong column/weak beam and the total number of columns $\left(\mathrm{I}_{\mathrm{scwB}}\right)$. Furthermore, the structure ductility $\left(R / \Omega_{0}\right)$ adopts Matsutaro Seki's procedures because the procedures have adapted ductility factors of the international earthquake regulations by inserting the factors of response modification $(R)$ and overstrength factors $\left(\Omega_{0}\right)$.

The column index $(\mathrm{I})$ is the ratio of the average column's shear force to the column ductility index that is modified from Matsutaro Seki and JBDPA procedures.

The distribution of the earthquake's shear force on the building structure follows the pattern called 'the higher the smaller', shear capacity, the story-shear modification factor, $\frac{n+1}{n+i}$ of JBDPA procedures is used.

$$
\begin{aligned}
& \left.\mathrm{E}_{0}=\frac{n+1}{n+i}\left(I_{A c-i} \cdot I_{C-i} \cdot I_{S C W B-i} \cdot I_{T}\right) \cdot \frac{R}{\Omega_{0}}\right] \\
& I_{A c-i}=\frac{\sum A_{C}}{\sum A_{C \min }} \\
& I_{C-i}=\frac{\left(N_{C-a} x 0.7\right)+\left(N_{C-b} x 0.8\right)+\left(N_{C-c} x 1.0\right)}{\Sigma N_{C}} \\
& I_{S C W B-i}=\frac{N_{S C W B}}{\sum N_{C}}
\end{aligned}
$$

\begin{tabular}{|c|c|}
\hline $\mathrm{E}_{0}$ & $=$ the basic seismic structure index for the moment-resisting frame. \\
\hline & $=$ the story-shear modification factor \\
\hline $\mathrm{n}$ & $=$ the number of levels of the building \\
\hline 11 & $\begin{array}{l}=\text { The evaluated level(s). Where the first level is given number } 1 \text { and the } \\
\text { followings are given } \mathrm{n} \text {. }\end{array}$ \\
\hline $\mathrm{I}_{\mathrm{AC}-\mathrm{i}}$ & $=$ column dimension index of the evaluated level \\
\hline $\mathrm{I}_{\mathrm{C}-\mathrm{i}}$ & $=$ column type index of the evaluated level \\
\hline ISCWE & $=$ strong column/weak beam index of the evaluated level \\
\hline & $\begin{array}{l}=\text { structural vibration period index, } \mathrm{T}_{\mathrm{c}} \leq \mathrm{T}_{\max } \rightarrow \mathrm{I}_{\mathrm{T}}=1 \text { and } \mathrm{T}_{\mathrm{C}}>\mathrm{T}_{\max } \rightarrow \mathrm{I}_{\mathrm{T}}=0 \\
=\text { structural vibration period based on the software calculation (in seconds) }\end{array}$ \\
\hline$T_{\max }$ & $\begin{aligned}= & \text { The maximally allowed structural vibration period (in seconds), article } \\
& 1617.4 .2 \text { of IBC } 2000 \text { (ICC, 2000) }\end{aligned}$ \\
\hline $\mathrm{R} / \Omega_{0}$ & $=$ the ductility index \\
\hline
\end{tabular}

Where, 
$\mathrm{R}$

$\Omega_{0}$

$\sum A_{C}$
$\sum A_{C \text { min }}$

$\mathrm{N}_{\mathrm{C}-\mathrm{a}}$

$\mathrm{N}_{\mathrm{C}-\mathrm{b}}$

$\mathrm{N}_{\mathrm{C}-\mathrm{c}}$

$0.7,0.8,1.0$

$\sum \mathrm{N}_{\mathrm{C}}$

$\mathrm{N}_{\mathrm{SCWB}}$
$=$ the response modification coefficient of moment-resisting frame of table 1617.6 IBC 2000 (ICC, 2000)

$=$ the system overstrength factor of moment-resisting frame of table 1617.6 IBC 2000 (ICC, 2000)

$=$ total design column area $\left(\mathrm{m}^{2}\right)$

$=$ total minimum column area $\left(\mathrm{m}^{2}\right)$ by $0.15 \%$ of the cumulative area of the column's load area (Ersoy, 2013), where the column should have a minimum area of $0.09 \mathrm{~m}^{2}$ or $0.3 \times 0.3 \mathrm{~m}$.

$=$ total of column types $-\mathrm{a}$ (table 3.1)

$=$ total of column types $-\mathrm{b}$ (table 3.1)

$=$ total of column types $-c$ (table 3.1 )

$=$ the index of columns types $a, b \& c$ (table 3.1)

$=$ total number of columns

= number of columns fulfill the $\mathrm{Wp}>1.2 \times \mathrm{Wp}$ beam, $\mathrm{Wp}=$ plastic modulus, $W p=0.25 x b x h^{2}$ and $W p=1 / 6 x d^{3}, b \& h=$ the dimensions of width and height of a beam or column, $d=$ column diameter (Bisch et al., 2012).

Table 3.1.The Combined Index of The Average Shear Stress and The Index of Structure Element Ductility (sources: processed from Okada et al., 2005; Seki, 2015))

\begin{tabular}{lccc}
\hline $\begin{array}{c}\text { Types ofLateral } \\
\text { Elements }\end{array}$ & \multicolumn{1}{c}{ Requirements } & $\begin{array}{c}\text { Index } \\
\text { (I) }\end{array}$ \\
\hline \multicolumn{1}{c}{ Columns } & $\begin{array}{c}\text { Clear Height } \\
\text { /Column } \\
\text { Depth; } \mathrm{h}_{0} / \mathrm{D}\end{array}$ & Definition $\mathrm{h}_{0} / \mathrm{D}$ & \\
\hline 1. Slender columns & $6 \leq \mathrm{h}_{0} / \mathrm{D}$ & & \\
2. Normal columns & $2<\mathrm{h}_{0} / \mathrm{D}<6$ & & 0.7 \\
\hline 3. Short columns & $\mathrm{h}_{0} / \mathrm{D} \leq 2$ & $\stackrel{\mathrm{D}}{\longrightarrow}$ & 0.8 \\
\hline
\end{tabular}

\subsubsection{The Irregularity Index $\left(S_{D}\right)$}

Several things to consider in the adaptation of the irregularity index are:

- Generally the guidance of either regular or irregular building configuration adopts the FEMA-451B procedures (FEMA, 2007). This guidance generally manages the configuration forms designed by architects, so it is more suitable to evaluate building irregularity in the design process. In addition, all international regulations related to earthquake have already adopted this guidance.

- Not all procedures in FEMA-451B are easy in its operation; especially for the architects in evaluating building irregularity in the process of design. Therefore, it needs code adoption and other researches that explain further about how to conduct the procedures.

- The applied scoring system of irregularity index adopts JBDPA procedures, but for the easy use, the scoring is divided into 3 levels namely light $=1$, fair $=0.75$, and heavy $=0.5$ with no adjustment factor. Therefore, the irregularity index is the multiplication between the item classification of irregular configuration and each of its evaluation level. 


$$
S_{D}=q_{a} \times q_{b} \times \ldots \ldots \ldots q_{i}
$$

Where,

$S_{D}=$ Irregularity index

$q_{a} \ldots . . . q_{i}=$ level of quality irregular configuration item $a$ to $i$

\section{a. Torsional Irregularity}

$$
e_{r}=e_{i} / w_{i}
$$

Where : $e_{r}=$ the ratio of the eccentricity length of the $i^{\text {th }}$ story $\left(e_{i}\right)$ to the width of the $i^{\text {th }}$ story of the building under study $\left(\mathrm{w}_{\mathrm{i}}\right)$.

Table 3.2. The Quality Level of The Eccentricity Ratio $\left(e_{r}\right)$ of Torsional Irregularity Configuration

\begin{tabular}{lccc}
\hline \multicolumn{1}{c}{ The source } & \multicolumn{3}{c}{ The quality level $\left(\mathbf{q}_{\mathrm{a}}\right)$} \\
\hline & $\mathbf{1}$ & $\mathbf{0 . 7 5}$ & $\mathbf{0 . 5}$ \\
\hline $\begin{array}{l}\text { JBDPA(Okada et } \\
\text { al., 2005) }\end{array}$ & $\mathrm{e}_{\mathrm{r}} \leq 0.1$ & $0.1<\mathrm{e}_{\mathrm{r}}<0.3$ & $\mathrm{e}_{\mathrm{r}} \geq 0.3$ \\
\hline
\end{tabular}

\section{b. Re-entrant Corner Irregularity}

$$
\mathrm{b}_{\mathrm{r}}=\mathrm{I}_{\mathrm{p}-\mathrm{i}} / \mathrm{I}_{\mathrm{u}-\mathrm{i}}
$$

Where $: b_{r}=$ the ratio of the area of the projection/wing of the $i^{\text {th }}$ story $\left(\mathrm{l}_{p-i}\right)$ of the building to the floor area of the $\mathrm{i}^{\text {th }}$ story of the main building $\left(\mathrm{l}_{\mathrm{u}-\mathrm{i}}\right)$.

Table 3.3. The Quality Level of The Building's Dimension Ratio $\left(b_{r}\right)$ of The Re-Entrant Corner Irregularity

\begin{tabular}{lccc}
\hline \multicolumn{1}{c}{ The sources } & \multicolumn{3}{c}{ The quality level $\left(\mathbf{q}_{\mathrm{b}}\right)$} \\
\hline $\begin{array}{l}\text { JBDPA (Okada et } \\
\text { al., 2005) }\end{array}$ & $\mathbf{1}$ & $\mathbf{0 . 7 5}$ & $\mathbf{0 . 5}$ \\
\hline $\begin{array}{l}\mathrm{b}_{\mathrm{r}} \leq 0.1 \\
\text { NZSSE (NZSEE, }\end{array}$ & $\begin{array}{c}\text { All wings } \\
\text { length/width } \\
\leq 3.0\end{array}$ & $\begin{array}{c}\text { One wing } \\
\text { length/width } \\
>3.0\end{array}$ & $\begin{array}{c}\text { Two or more } \\
\text { wings length/ } \\
\text { width }>3.0, \text { or } \\
\text { one wing } \\
\text { length/width }>4\end{array}$ \\
Recommendations & $\begin{array}{c}\text { All wings } \\
\mathrm{b}_{\mathrm{r}} \leq 0.1\end{array}$ & $\begin{array}{c}\text { One wing } \\
0.1<\mathrm{b}_{\mathrm{r}}<0.3\end{array}$ & $\begin{array}{c}\text { Two or more } \\
\text { wings } \mathrm{b}_{\mathrm{r}} \geq 0.3\end{array}$ \\
\hline
\end{tabular}

\section{c. Diaphragm Discontinuity Irregularity}

$$
e_{v}=\sum I_{b-i} / \sum I_{-i}
$$

Where $: e_{v}=$ the ratio of the hole area of voids, the shafts, the stairs, the elevators, etc. of the $\mathrm{i}^{\text {th }}$ story $\left(\mathrm{l}_{\mathrm{b}-\mathrm{i}}\right)$ to the floor area of the $\mathrm{i}^{\text {th }}$ story $\left(\mathrm{l}_{\mathrm{l}-\mathrm{i}}\right)$. 
Tabel 3.4. The Quality Level of TheOpening Void Ratio $\left(e_{v}\right)$ of The Diaphragm Discontinuity Configuration

\begin{tabular}{lccc}
\hline \multicolumn{1}{c}{ The source } & \multicolumn{3}{c}{ The quality level $\left(\mathbf{q}_{\mathrm{c}}\right)$} \\
\hline & $\mathbf{1}$ & $\mathbf{0 . 7 5}$ & $\mathbf{0 . 5}$ \\
\hline $\begin{array}{l}\text { JBDPA (Okada } \\
\text { et al., 2005) }\end{array}$ & $\mathrm{e}_{\mathrm{v}} \leq 0.1$ & $0.1<\mathrm{e}_{\mathrm{v}}<0.3$ & $\mathrm{e}_{\mathrm{v}} \geq 0.3$ \\
\hline
\end{tabular}

\section{d. Nonparallel Systems Irregularity}

$$
\mathrm{j}_{\mathrm{r}}=\sum \mathrm{j}_{\mathrm{i}} / \sum \mathrm{j}_{\mathrm{t}-\mathrm{i}}
$$

Where, $\mathrm{j}_{\mathrm{r}}=$ the ratio of the number of the elements of beams, columns, and/or shear wall which do not follow the orthogonal axis $\left(\sum \mathrm{i}_{\mathrm{i}}\right)$ of the $\mathrm{i}^{\text {th }}$ story to the total number of the elements of beams, columns, and/or shear wall of the $\mathrm{i}^{\text {th }}$ story $\left(\sum \mathrm{j}_{\mathrm{t}-\mathrm{i}}\right)$.

Tabel 3.5. The Quality Level of The Ratio Number of Beam \& Column Elements $\left(j_{r}\right)$ of Nonparallel System Irregularity Configuration

\begin{tabular}{lccc}
\hline The source & \multicolumn{3}{c}{ The quality level $\left(\mathbf{q}_{\mathrm{d}}\right)$} \\
\hline & $\mathbf{1}$ & $\mathbf{0 . 7 5}$ & $\mathbf{0 . 5}$ \\
\hline $\begin{array}{l}\text { JBDPA } \\
\text { (Okada et } \\
\text { al., 2005) }\end{array}$ & $\mathrm{j}_{\mathrm{r}}<0.3$ & $0.3 \leq \mathrm{j}_{\mathrm{r}} \leq 0.5$ & $\mathrm{j}_{\mathrm{r}}>0.5$ \\
\hline
\end{tabular}

\section{e. Stiffness (Soft Story) Irregularity}

$$
I_{r}=I_{i+1} / I_{i}
$$

Where : $I_{r}=$ the ratio of the height of the column of the story one level higher than the $\mathrm{i}^{\text {th }}$ story $\left(l_{i+1}\right)$ to the height of the column of the $i^{\text {th }}$ story $\left(l_{i}\right)$.

Tabel 3.6. The Quality Level of The Column's Height Ratio $\left(I_{r}\right)$ of Soft Story Configuration

\begin{tabular}{lccc}
\hline The source & \multicolumn{3}{c}{ The quality level $\left(\mathbf{q}_{\mathrm{e}}\right)$} \\
\hline & $\mathbf{1}$ & $\mathbf{0 . 7 5}$ & $\mathbf{0 . 5}$ \\
\hline $\begin{array}{l}\text { JBDPA } \\
\text { (Okada et al., }\end{array}$ & $\mathrm{I}_{\mathrm{r}} \geq 0.8$ & $0.7 \leq \mathrm{I}_{\mathrm{r}}<0.8$ & $\mathrm{I}_{\mathrm{r}}<0.7$ \\
2005) & & & \\
\hline
\end{tabular}

\section{f. Weight (Mass) Irregularity}

$$
m_{r}=\sum m_{i} / \sum m_{i+1}
$$

Where : $m_{r}=$ the ratio of the floor mass of the $i^{\text {th }}$ story $\left(m_{i}\right)$ to the floor mass of the story one level higher than the $\mathrm{i}^{\text {th }}$ story $\left(\mathrm{m}_{\mathrm{i}+1}\right)$. 
Tabel 3.7. The Quality Level of The Floor's Mass Ratio $\left(m_{r}\right)$ of Weight / Mass Irregularity Configuration

\begin{tabular}{lccc}
\hline The source & \multicolumn{3}{c}{ The quality level $\left(\mathrm{q}_{\mathrm{f}}\right)$} \\
\hline & $\mathbf{1}$ & $\mathbf{0 . 7 5}$ & $\mathbf{0 . 5}$ \\
\hline $\begin{array}{l}\mathrm{NZSSE} \\
\text { (NZSEE, }\end{array}$ & $\mathrm{m}_{\mathrm{r}} \leq 1$ & $1<\mathrm{m}_{\mathrm{r}} \leq 1.5$ & $\mathrm{~m}_{\mathrm{r}}>1.5$ \\
$2006)$ & & & \\
\hline
\end{tabular}

\section{g. Vertical Geometric Irregularity}

$$
\mathrm{S}_{\mathrm{r}}=\mathrm{A}_{\mathrm{i}} / \mathrm{L}_{\mathrm{i}}
$$

Where, $s_{r}=$ the ratio of the building length $(L)$ of the $i^{\text {th }}$ story to the building setback length $(A)$ of the $\mathrm{i}^{\text {th }}$ story.

Table 3.8. The Quality Levels of The Ratio of The Building Length And Set Back Length $\left(\mathrm{s}_{\mathrm{r}}\right)$ of The Vertical Geometric Irregularity Configuration

\begin{tabular}{lccc}
\hline \multicolumn{1}{c}{ The Sources } & \multicolumn{3}{c}{ The quality level $\left(\mathbf{q}_{\mathrm{g}}\right)$} \\
\hline & $\mathbf{1}$ & $\mathbf{0 . 7 5}$ & $\mathbf{0 . 5}$ \\
\hline $\begin{array}{l}\text { Bureau Of Indian } \\
\text { Standards (BIS, }\end{array}$ & $\mathrm{s}_{\mathrm{r}}<0.1$ & - & - \\
2002) & & & \\
$\begin{array}{l}\text { FEMA 451B } \\
\text { (FEMA, 2007) }\end{array}$ & - & - & $\mathrm{s}_{\mathrm{r}}>0.3$ \\
Recommendation & $\mathrm{s}_{\mathrm{r}} \leq 0.1$ & $0.1<\mathrm{s}_{\mathrm{r}}<0.3$ & $\mathrm{~s}_{\mathrm{r}} \geq 0.3$ \\
\hline
\end{tabular}

\section{h. Story Strength (Weak Story) Irregularity}

$\mathrm{a}_{\mathrm{r}}=\left(\sum \mathrm{a}_{\mathrm{e}}\right)_{i} /\left(\sum \mathrm{a}_{\mathrm{e}}\right)_{i+1}$

Where, $a_{r}=$ the ratio of the column area of the $\mathrm{i}^{\text {th }}$ story $\left(\sum \mathrm{a}_{\mathrm{e}}\right)_{\mathrm{i}}$ and the column area of the story one level higher than the $i^{\text {th }}$ story $\left(\sum a_{e}\right)_{i+1}$.

Table 3.9. The Quality Level of The Column's Width Ratio $\left(a_{r}\right)$ of The Weak Story Configuration

\begin{tabular}{lccc}
\hline \multicolumn{1}{c}{ The source } & \multicolumn{3}{c}{ The quality level $\left(\mathbf{q}_{\mathrm{h}}\right)$} \\
\hline & $\mathbf{1}$ & $\mathbf{0 . 7 5}$ & $\mathbf{0 . 5}$ \\
\hline $\begin{array}{l}\text { Turkish } \\
\text { Earthquake } \\
\text { Code } \\
\text { (Earthquake }\end{array}$ & & & \\
$\begin{array}{l}\text { Research } \\
\text { Departement, }\end{array}$ & $\mathrm{a}_{\mathrm{r}}>0.8$ & $0.65 \leq \mathrm{a}_{\mathrm{r}} \leq 0.8$ & $\mathrm{a}_{\mathrm{r}}<0.65$ \\
2007) & & & \\
\hline
\end{tabular}




\section{i. Out of Plane Offsets and In-Plane Discontinuity Irregularity}

$$
\mathrm{d}_{\mathrm{r}}=\sum \mathrm{d}_{\mathrm{i}} / \sum \mathrm{l}_{\mathrm{i}}
$$

Where, $d_{r}=$ the ratio of the brick wall area of the floor of the $i^{\text {th }}$ story $\left(\sum d_{i}\right)$ and the floor area of the $\mathrm{i}^{\text {th }}$ story $\left(\sum \mathrm{i}_{\mathrm{i}}\right)$.

Table 3.10. The Quality Level of The Wall Density Ratio $\left(d_{r}\right)$ of The Plane Irregularity Configuration

\begin{tabular}{cccc}
\hline The Sources & \multicolumn{3}{c}{ The quality level $\left(\mathbf{q}_{\mathrm{i}}\right)$} \\
\hline & $\mathbf{1}$ & $\mathbf{0 . 7 5}$ & $\mathbf{0 . 5}$ \\
\hline (Alwashali and Maeda, & $\mathrm{d}_{\mathrm{r}}>1.5 \%$ & $1 \% \leq \mathrm{d}_{\mathrm{r}} \leq 1.5 \%$ & $\mathrm{~d}_{\mathrm{r}}<1 \%$ \\
2012) & - & $\mathrm{d}_{\mathrm{r}} \geq 1 \%$ & $\mathrm{~d}_{\mathrm{r}}<1 \%$ \\
$\begin{array}{c}\text { (Boen, Arya and } \\
\text { Ishiyama, 2014) }\end{array}$ & - & $1 \% \leq \mathrm{d}_{\mathrm{r}} \leq 1.5 \%$ & $\mathrm{~d}_{\mathrm{r}}<1 \%$ \\
\hline Recommendation & $\mathrm{d}_{\mathrm{r}}>1.5 \%$ & & \\
\hline
\end{tabular}

Table 3.11: The Irregularity Index $\left(\mathrm{S}_{\mathrm{D}}\right)$ Recapitulation

\begin{tabular}{|c|c|c|c|c|c|}
\hline & & & \multicolumn{3}{|c|}{ Level of Quality (q) } \\
\hline & & & 1.0 & 0.75 & 0.5 \\
\hline \multirow{4}{*}{$\begin{array}{l}\text { Horizontal } \\
\text { Structural } \\
\text { Irregularities }\end{array}$} & a & $\begin{array}{l}\text { Torsional } \\
\text { Irregularity }\end{array}$ & $e_{r} \leq 0.1$ & $0.1<e_{r}<0.3$ & $e_{r} \geq 0.3$ \\
\hline & $b$ & $\begin{array}{l}\text { Re-entrant } \\
\text { Corner } \\
\text { Irregularity }\end{array}$ & $\begin{array}{c}\text { All Wings } \\
b_{r} \leq 0.1\end{array}$ & $\begin{array}{l}\text { One of the } \\
\text { wings } \\
0.1<b_{r} \leq 0.3\end{array}$ & $\begin{array}{c}\text { Two or } \\
\text { more } \\
\text { wings } \\
b_{r}>0.3\end{array}$ \\
\hline & C & $\begin{array}{l}\text { Diaphragm } \\
\text { Discontinuity } \\
\text { Irregularity }\end{array}$ & $e_{v} \leq 0.1$ & $0.1<e_{v}<0.3$ & $e_{v} \geq 0.3$ \\
\hline & $d$ & $\begin{array}{l}\text { Nonparallel } \\
\text { Systems } \\
\text { Irregularity }\end{array}$ & $\mathrm{j}_{\mathrm{r}}<0.3$ & $0.3 \leq \mathrm{j}_{\mathrm{r}} \leq 0.5$ & $\mathrm{j}_{\mathrm{r}}>0.5$ \\
\hline \multirow{4}{*}{$\begin{array}{c}\text { Vertical } \\
\text { Structural } \\
\text { Irregularities }\end{array}$} & e & $\begin{array}{l}\text { Stiffness (Soft } \\
\text { Story) } \\
\text { Irregularity }\end{array}$ & $\mathrm{I}_{\mathrm{r}} \geq 0.8$ & $0.7 \leq \mathrm{I}_{\mathrm{r}}<0.8$ & $\mathrm{I}_{\mathrm{r}}<0.7$ \\
\hline & $f$ & $\begin{array}{l}\text { Weight (Mass) } \\
\text { Irregularity }\end{array}$ & $m_{r}<1$ & $1 \leq m_{r} \leq 1.5$ & $m_{r}>1.5$ \\
\hline & $g$ & $\begin{array}{l}\text { Vertical } \\
\text { Geometrical } \\
\text { Irregularity }\end{array}$ & $\mathrm{s}_{\mathrm{r}} \leq 0.1$ & $0.1<s_{r}<0.3$ & $\mathrm{~s}_{\mathrm{r}} \geq 0.3$ \\
\hline & $\mathrm{h}$ & $\begin{array}{l}\text { Story Strength } \\
\text { (Weak Story) } \\
\text { Irregularity }\end{array}$ & $a_{r} \geq 0.8$ & $0.65 \leq a_{r}<0.8$ & $a_{r}<0.65$ \\
\hline $\begin{array}{l}\text { Horizontal } \\
\text { and Vertical } \\
\text { Structural } \\
\text { Irregularities }\end{array}$ & $\mathrm{i}$ & $\begin{array}{l}\text { Out of Plane } \\
\text { Offsets and In- } \\
\text { Plane } \\
\text { Discontinuity } \\
\text { Irregularity }\end{array}$ & $d_{r}>1.5 \%$ & $1 \% \leq d_{r} \leq 1.5 \%$ & $d_{r}<1 \%$ \\
\hline
\end{tabular}




\subsection{The Adaptation of The Seismic Demand Index of Structure (Iso)}

The seismic demand index of structure was adopted from several procedures based on the following reasons:

- Generally the seismic demand index of structure was adopted from Matsutaro Seki procedures (Seki, 2015) because it had been adjusted to the international earthquake regulations-IBC2000 (ICC, 2000).

- For seismic response coefficient $\left(\mathrm{C}_{\mathrm{S}}\right)$ and earthquake primacy factors $\left(\mathrm{I}_{\mathrm{e}}\right)$, they adopted IBC 2000(ICC, 2000).

- The distribution of earthquake forces in the structure follows 'the higher the bigger'

patterns (Ishiyama, 2011).Therefore to evaluate distribution of the building level's earthquake force, the story-seismic demand modification factor ('the higher the bigger') is used, which is the inverse of the story-shear modification factor $\frac{n+i}{2 n-i+1}$.

$$
\begin{aligned}
\mathrm{I}_{\mathrm{SO}} & =\frac{n+i}{2 n-i+1}\left(\mathrm{I}_{\mathrm{CS}} . \mathrm{I}_{\mathrm{e}}\right) \\
I_{C S} & =\frac{C_{S}}{C_{S \text { min }}}
\end{aligned}
$$

Where $I_{\text {so }}=$ seismic demand index $\mathrm{n}=$ number of building levels; $\mathrm{i}=$ evaluated level(s), where the first level is given number 1 and the followings are given $\mathrm{n} ; \frac{n+i}{2 n-i+1}=$ modification factor of seismic demand of the levels, following the distribution of $\quad ; \mathrm{C}_{\mathrm{S}}=$ Seismic response coefficient of the design based on formulations 21-25 of SNI 1726:2012 or formulation 26 of SNI 1726:2002; $C_{S \min }=$ minimum seismic response coefficient $S_{S}=0.25 \mathrm{~g}$ and $S_{1}=0.1 \mathrm{~g}$ based on FEMA 155 (FEMA 2015) or zone 2A of UBC 1997 (Code, 1997); I IS = seismic response coefficient index; $\mathrm{I}_{\mathrm{e}}=$ primary factor of building function table $1 \& 2$ of SNI 1726:2012 (BSN, 2012) or table 1 of SNI 1726:2002 (BSN, 2002).

\subsection{The Adaptation of Seismic Index of Structure ( $\left.I_{S}\right)$ vs Seismic Demand Index of Structure (Iso)}

As mentioned earlier, the basic principle of earthquake-resistant building is that the capacity of the building's structure must be larger than the lateral load of the earthquake, or it must be according to the formula:

$$
I_{S} \geq I_{\text {SO }}
$$

Where, $I_{S}=$ seismic structure index; $I_{s o}=$ seismic demand index. To evaluate the vulnerability of a building's structure, the seismic index of structure and the seismic demand index of structure can be compared and each level can inform possible level of building damage (table 3.12). 
Table 3.12. The Recommendation of Potential Seismic Vulnerability Evaluation Based on Seismic Performances (Source: Modification of Seki Procedure Seki, 2015))

\begin{tabular}{|c|c|c|c|}
\hline $\begin{array}{l}\text { Seismic } \\
\text { vulnerability } \\
\text { evaluation }\end{array}$ & $\begin{array}{l}\text { Potential level } \\
\text { of damage }\end{array}$ & Seism & $\begin{array}{l}\text { performance-FEMA } 273 \\
\text { (FEMA 1997) }\end{array}$ \\
\hline$I_{S}>I_{S O}$ & $\begin{array}{c}\text { Slightly } \\
\text { damaged }\end{array}$ & $<0.5 \%$ & IO (ImmediateOccupancy) \\
\hline $0.5 \mathrm{I}_{\mathrm{SO}} \leq \mathrm{I}_{\mathrm{S}} \leq \mathrm{I}_{\mathrm{sO}}$ & $\begin{array}{c}\text { Fairly } \\
\text { damaged }\end{array}$ & $<1.5 \%$ & LS (Life Safety) \\
\hline$I_{S}<0.5 I_{s O}$ & $\begin{array}{c}\text { Heavily } \\
\text { damaged }\end{array}$ & $<2.5 \%$ & CP (Collapse Prevention) \\
\hline
\end{tabular}

The seismic performance based on FEMA 273 in table 3.12 is used to compare SVAArchitectural Design method with Pushover analysis method, so the validity level is known. The Pushover analysis is good enough in evaluating seismic performance of low rise to middle rise buildings (Poleswara Rao Kovela et al., 2017).

\section{The Manual}

Finding out the buildings'vulnerability towards earthquakes is done by evaluating each floor, so the vulnerability of each floor can be exposed. The stages in how to evaluate the vulnerability of buildings' structures and geometry towards earthquakes are described below:

- Calculate thestory-shear modification factor, calculate the index of the evaluated level's column element dimension $\left(\mathrm{I}_{\mathrm{Ac}-\mathrm{i}}\right)$ (formula 3 ), calculate the index of the evaluatedlevel's column type $\left(\mathrm{I}_{\mathrm{C}_{-}}\right)$(formula 4 ), calculate the strong column / weak beam index of the evaluated level ( $I_{\text {SCWB-i }}$ ) (formula 5 ), obtain the $T_{C}$ value from the software calculation (like SAP2000 or Etabs) and compare it with $T_{\max }$ so the index of the structure's vibration period $\left(\mathrm{I}_{\mathrm{T}}\right)$ is acquired, obtain $\mathrm{R}$ and $\Omega_{0}$ from the table 1617.6 IBC 2000 then calculate the ductility of structure $\mathrm{R} / \Omega_{0}$. Multiply the story-shear modification factor by all structure indices to obtain the basic seismic index of structure's $\left(E_{0}\right)$ (the formula 2).Calculate each irregularity of building's geometry based on the formula 7 to 15 then multiply the values of each irregularity $(q)$, so the value of the irregularity index $\left(S_{D}\right)$ (formula 6 ) can be obtained. Multiply the basic seismic index of structure's $\left(E_{0}\right)$ by the irregularity index $\left(S_{D}\right)$ to get the seismic index of structure $\left(I_{S}\right)$ (the formula 1 ).

- Calculate the story-seismic demand modification factor, calculate $\mathrm{C}_{\mathrm{s}}$ and $\mathrm{C}_{\mathrm{Smin}}$ then calculate it with the formula 17 to get the value of the seismic response index $\left(I_{C S}\right)$. Obtain the value of the building's primacy function factor $\left(\mathrm{I}_{\mathrm{e}}\right)$ from the table 1604.5 IBC 2000 and then multiply all the story-seismic demand modification factor, the seismic response index $\left(I_{c s}\right)$ and primacy factors of building's function $\left(I_{e}\right)$ to obtain the seismic demand index of structure ( $\left.I_{\text {so }}\right)$ (formula 16$)$.

- Compare the $I_{S}$ and $I_{s o}$ values (the formula 18) based on the regulations of table 3.12 , so the level of building's potential vulnerability towards the earthquake can be obtained whether it is lightly damaged, fairly damaged or heavily damaged. 

with The SVA-Architectural Design

\subsection{Example}

The object of this study is a two-story school located at the Area 2 of Earthquake Zones SNI 1726:2002 (BSN, 2002) having floor to floor height $3.6 \mathrm{~m}$, concrete quality $15.1 \mathrm{Mpa}$, and quality reinforcement $287.2 \mathrm{MPa}$ and $477.2 \mathrm{Mpa}$ with ordinary reinforced concrete moment frame. The dimensions of beams and columns can be seen in Figure 4.1.



Figure 4.1.The Beam Layout Plan of the School Building (Adapted from : Dirgantari and Wahyuni, 2014)

Table 4.1.The Seismic Index of Structure $\left(I_{S-i}\right)$ of the School Model (Source: Analysis)

\begin{tabular}{rlllllllllll}
\hline Model & Floor & $\frac{n+1}{n+i}$ & $I_{A c-i} \cdot I_{C-i}$ & $I_{S C W B-i}$ & $I_{T}$ & $\mathbf{R}$ & $\mathbf{\Omega o}$ & $\mathbf{E}_{\mathbf{0 - i}}$ & $\mathbf{S}_{\mathbf{D}-\mathbf{i}}$ & $\mathbf{I}_{\mathbf{S}-\mathbf{i}}$ \\
\hline \multirow{2}{*}{ School } & $\begin{array}{l}\text { Second } \\
\text { Floor }\end{array}$ & $3 / 3$ & 1.00 & 1.47 & 0.47 & 0.00 & 3.5 & 2.8 & 0.00 & 0.38 & 0.00 \\
& Roof & $3 / 4$ & 0.75 & 1.47 & 0.18 & 0.00 & 3.5 & 2.8 & 0.00 & 0.38 & 0.00 \\
\hline
\end{tabular}


Table 4.2. Seismic Demand Index of Structure (I $\left.\mathrm{ISO}_{\text {-i }}\right)$ of School Location Model (Source: Analysis)

\begin{tabular}{c|cccccc}
\hline Model & Floor & $\frac{n+i}{2 n-i+1}$ & $\mathbf{I}_{\text {CS }}$ & $\mathbf{I}_{\mathbf{e}}$ & $\mathbf{I}_{\text {so-i }}$ \\
\hline School & $\begin{array}{c}\text { Second } \\
\text { Floor }\end{array}$ & $3 / 4$ & 0.75 & 1.00 & 1.00 & 0.75 \\
& Roof & $3 / 3$ & 1.0 & 1.00 & 1.00 & 1.00 \\
\hline
\end{tabular}

Table 4.3. The Comparison of the Seismic Index of Structure $\left(I_{S-i}\right)$ and Seismic Demand Index of Structure $\left(\mathrm{I}_{\text {SO-i }}\right)$ and the Comparison of SVA and Pushover Analysis of the School Model (Source: Analysis)

\begin{tabular}{cccccccc}
\hline Model & Floor & $I_{\text {S-i }}$ & $I_{\text {so-i }}$ & SVA & \multicolumn{2}{c}{$\begin{array}{c}\text { Pushover analysis- } \\
\text { SAP2000 }\end{array}$} \\
\cline { 6 - 7 } School & & & & & $\begin{array}{c}\text { drift } \\
\text { ratio (\%) }\end{array}$ & $\begin{array}{c}\text { Performance } \\
\text { Level }\end{array}$ \\
\hline \multirow{2}{*}{ second } & Floor & 0.00 & 0.75 & CP & $1.76 \%$ & LS-CP \\
& Roof & 0.00 & 1.00 & CP & & \\
\hline
\end{tabular}

In table 4.1 , the value of $\mathrm{I}_{\mathrm{S}-\mathrm{i}}$ is the multiplication of $\mathrm{E}_{0-\mathrm{i}}$ and $\mathrm{S}_{\mathrm{D}-\mathrm{i}} . \mathrm{E}_{0-\mathrm{i}}$ is the basic seismic structure index of ordinary reinforced concrete moment frame which is the multiplication result of the story-shear modification factor $\left(\frac{n+1}{n+i}\right)$, the column dimension index $\left(I_{A c-i}\right)>1$, the column type index $\left(I_{C-i}\right)=0.8$ normal columns $(2<\mathrm{h} 0 / \mathrm{D}<6)$, the strong column/weak beam index $\left(I_{S C W B-i}\right)=1$; except the rooftop $=0.31$, structural vibration period index $\left(\mathrm{I}_{\mathrm{T}}\right)=0$ since $\mathrm{T}_{\mathrm{C} \text { - }}$ $y=0.537$ seconds $>T_{\max }=0.38$ seconds, the ductility index $\left(R / \Omega_{0}\right)=3.5 / 2.8$ and $S_{D-i}$ is irregularity index or index of the building geometric irregularity since this school model has irregular geometry form from the combination of torsional irregularity configuration and the setback; hence its irregularity index $\left(\mathrm{S}_{\mathrm{D}-\mathrm{i}}\right)=0.38$.

In Table 4.2, $\mathrm{I}_{\mathrm{SO}_{-} \mathrm{i}}$ is seismic demand index of structure which is the multiplication of the storyseismic demand modification factor $\left(\frac{n+i}{2 n-i+1}\right)$, seismic response coefficient index $\left(\mathrm{I}_{\mathrm{CS}}\right)=1.0$ and primary factor of building function $\left(\mathrm{I}_{\mathrm{e}}\right)=1$ (school). The table 4.3 shows that the comparison from the second floor to the roof is $I_{S}<0.5 I_{S O}(C P)$. It means the dimensions of columns, beams, and building geometry were not well-designed, and such condition creates inadequate stiffness, strength, and ductility; hence potential heavy damage or CP (Collapse Prevention) during a strong earthquake.

In table 4.3, the research result of Dirgantari (Dirgantari and Wahyuni, 2014) in this model, employing the pushover analysis, yielded target displacement $=0.127 \mathrm{~m}$ with drift ratio $=1.76 \%$. According to FEMA 273, the model, located at the Earthquake Area 2 where 
the hard soil in inelastic condition, is able to hold seismic loads to the level of Life Safety(LS) - Collapse Prevention (CP). At such level, the condition of the building is irreparable. The prediction of SVA procedures which is proposed is almost similar to the research result of Dirgantari.

\section{Conclusion}

The proposed SVA-Architectural Design does not intend to accurately predict the buildings'svulnerability towards earthquakes. However,as Sinha and Goyal (Sinha and Goyal, 2004) explained, SVA is the initial prediction of the building's vulnerability towards the earthquake.Therefore, either the architects who then make efforts to find solutions for the design; or by structure experts who can conduct detailed analysis.

The aforementioned example has shown that the SVA analysis is relatively accurate in predicting the building vulnerability in comparison with the Pushover analysis.

\section{References}

Alwashali, H. and Maeda, M. (2012) 'Study of Seismic Evaluation Methods Of RC Buildings With Masonry Infill Walls; A Case Study of Building in Jordan', in Japan Association for Earthquake Engineering (JAEE) (ed.) International Symposium on Earthquake Engineering, JAEE, Vol.1. Tokyo: JAEE, pp. 497-506.

Arnold, C. (1996) 'Architectural Aspects of Seismic Resistant Design', in Eleventh World Conference on Earthquake Engineering. Elsevier Science Ltd.

BIS (2002) Criteria for Earthquake Resistant Design of Structures Part 1 General Provisions and Buildings - IS 1893( Part 1):2002. New Delhi: Bureau of Indian Standards (BIS).

Bisch, P. et al. (2012) Eurocode 8: Seismic Design of Buildings Worked examples. Luxembourg: doi: 10.2788/91658.

Boen, T. (2006) The Yogya Earthquake 27 May 2006, Structural Damage Report.

Boen, T. (2007a) Bengkulu \& West Sumatra Earthquakes, September 12, 2007, Structural Damage Report.

Boen, T. (2007b) 'West Sumatra Earthquake, 6 March 2007, Structural Damage Report', in HAKI (ed.) Konstruksi Tahan Gempa Indonesia. Jakarta: HAKI, pp. 1-30.

Boen, T., Arya, A. S. and Ishiyama, Y. (2014) Guidelines for Earthquake Resistant NonEngineered Construction. UNESCO.

BSN (2002) Standar Perencanaan Ketahanan Gempa Untuk Struktur Bangunan GedungSNI 1726 : 2002. Jakarta: Badan Standar Nasional.

BSN (2012) Tata Cara Perencanaan Ketahanan Gempa Untuk Struktur Bangunan Gedung dan Non Gedung - SNI 1726: 2012. Jakarta: Badan Standar Nasional.

Code, U. B. (1997) 'UBC. 1997', in International Conference of Building Officials, Uniform Building Code, Whittier, California.

Çögürcü, M. T. (2015) 'Construction And Design Defects In The Residential Buildings And Observed Earthquake Damage Types In Turkey', Natural Hazards and Earth System Sciences, 3(C187-C187), pp. 1-26.

Dirgantari, W. and Wahyuni, E. (2014) 'Studi Assessment Kerentanan Gedung Beton Bertulang Terhadap Beban Gempa Dengan Menggunakan Metode Pushover Analysis', ITS Library. Surabaya, pp. 1-6.

Earthquake Research Departement (2007) Turkish Earthquake Code (TEC). General Directorate of Minister Affairs.

Ersoy, U. (2013) 'A Simple Approach for Preliminary Design of Reinforced Concrete Structures to be Built in Seismic Regions', Teknik Dergi, 24(4), pp. 6559-6574.

FEMA (2007) NEHRP Recommended Provisions for New Buildings and Other Structures: 
Training and Instructional Materials-FEMA 451B. Washington DC: Federal Emergency Management Agency (FEMA).

FEMA (2015) Rapid Visual Screening of Buildings for Potential Seismic Hazards: Supporting Documentation-FEMA 155. Washington DC: Federal Emergency Management Agency (FEMA).

ICC (2000) International Building Code-IBC2000. California: International Conference of Building Officials.

Ishiyama, Y. (2011) 'Introduction to Earthquake Engineering and Seismic Codes in the World', Hokkaido University, Hokkaido, Japan.

Ismail, F. A., Hakam, A. and Fauzan (2011) 'Kerusakan Bangunan Hotel Bumi Minang Akibat Gempa Padang 30 September 2009', Jurnal Teknik Sipil, Vol. 18(No. 2), pp. 119-125.

NZSEE (2006) Assessment and Improvement of the Structural Performance of Buildings in Earthquakes. Wellington: New Zealand Society for Earthquake Engineering (NZSEE).

Okada, T. et al. (eds) (2005) Guidelines for Seismic Retrofit of Existing Reinforced Concrete Buildings. Tokyo: The Japan Building Disaster Prevention Association (JBDPA).

Özmen, C. and Ünay, A. I. (2007) 'Commonly encountered seismic design faults due to the architectural design of residential buildings in Turkey', Building and Environment, 42(3), pp. 1406-1416. doi: 10.1016/j.buildenv.2005.09.029.

Pawirodikromo, W. (2007) 'Kerusakan Bangunan Pada Gempa Yogyakarta 27 Mei 2006 : Akibat Kebelum Jelasan Code, Sosialisasi atau Pelaksanaan?', in HAKI (ed.) Konstruksi Tahan Gempa Indonesia. Jakarta: HAKI, pp. 1-17.

Pelling, M. et al. (2004) Reducing Disaster Risk A Challenge for Development. New York.

Poleswara Rao Kovela et al. (2017) 'Effect of Increase of Reinforcement Near Beam Column Joints in Performance Based Design of Low-RiseBuildings', International Journal of Engineering and Technology, 9(3), pp. 2605-2618. doi: 10.21817/ijet/2017/v9i3/1709030309.

Purwono, R. (2007) Evaluasi Cepat Sistem Rangka Pemikul Momen Tahan Gempa Sesuai SNI 03-2847-2002 dan SNI 03-1726-2002. Surabaya: Itspress.

Seki, M. (2015) 'A Proposal on the Simplified Structural Evaluation Method for Existing Reinforced Concrete Buildings Based on the Japanese Seismic Evaluation Standard vis-a-vis the International Seismic Code', Journal of Earthquake Science and Engineering, 2(1), pp. 14-24.

Sinha, R. and Goyal, A. (2004) 'A National Policy for Seismic Vulnerability Assessment of Buildings and Procedure for Rapid Visual Screening of Buildings for Potential Seismic Vulnerability', http://www. civil.iitb.ac.in/ rsinha/Vulnerability_Assessment.pdf.

Slak, T. and Kilar, V. (2012) 'Parameterization and Evaluation of Seismic Resistance within the Context of Architectural Design', Modern Applied Science, 6(7). doi: 10.5539/mas.v6n7p17.

Wangsadinata, W. (2009) 'Arsitektur Sebagai Seni Struktur', in Budihardjo, E. (ed.) Pengaruh Budaya dan Iklim Dalam Perancangan Arsitektur. Bandung: PT. Alumni. 